\title{
The Identity Constitution of the Craft Beer Consumer in the City of Fortaleza (Brazil)
}

\author{
João Gonçalves Menezes Filho ${ }^{1}$ \\ joaofilhobox@gmail.com | @0000-0002-4323-1306 \\ Minelle E. Silva ${ }^{1}$ \\ minele.adm@gmail.com | (1D0000-0003-2074-6478 \\ José Sarto Freire Castelo ${ }^{1}$ \\ sarto@unifor.br| (10)0000-0003-3552-9986
}

\begin{abstract}
With the transformation of the market into a provider of relevant symbolic resources, individuals like to demonstrate consumer goods that reflect their values and shared lifestyles. Thus, the aim of this study is to define identity profiles of craft beer enthusiasts based on their consumption practices. Using exploratory qualitative research, 55 consumers were interviewed and observations were made in the city of Fortaleza, Ceará, Brazil. The results present five consumer identity profiles in the culture of the craft beer consumer: Beginner, Adventurer, Beer Evangelist, Expert, and Beer Snob. The research enriches the studies inherent in consumer culture by presenting identity profiles based on consumption habits, and what is more, the research also makes a contribution by presenting the segmentation methodology in which the suggested identities can serve as a mechanism for industry organizations in the search for relationship strategies with the target audience.
\end{abstract}

\section{KEYWORDS}

Consumer Culture, Identity Profiles, Craft Beer

\author{
${ }^{1}$ Universidade de Fortaleza, \\ Forteleza, CE, Brasil




\section{INTRODUCTION}

Culture, consumption, and identity are strongly interconnected in modern society, since the link between lived culture and social resources, as well as between relevant lifestyles and material and symbolic resources, are subject to market moderation (Arnould \& Thompson, 2005). Thus, it is understood that the act of consuming itself has begun to invoke meanings which are increasingly distant from the functional benefits obtained from the act of consumption, continuously, through its use, incorporating aspects of identification and differentiation (McCracken, 2003). That is, when an individual consumes, s/he is not only appropriating the functional value of a product, or announcing her/his preference, s/he is also expressing their identity (Barbosa \& Campbell, 2006).

Bagozzi and Dholakia (2006) state that people manifest a predisposition to label themselves, and to organize other individuals into social categories. Human beings identify with things and subjects that share similar characteristics (Hassay \& Peloza, 2009), and with groups that they perceive as significant in relation to their particular interests and values (Bhattacharya \& Elsbach, 2002). Many times, this perception of belonging relates to consumer groups that share social affinities through the use of a brand or product, these are known as consumer cultures (Schouten \& McAlexander, 1995; Füller, Matzler \& Hoppe, 2008; Schau, Muñiz Jr., \& Arnould, 2009).

In this context, it is understood that the consumption of craft beer presents an interesting context that should also be studied in the light of consumer culture, due to the fact that compared to consumers of industrialized beers, lovers of craft beers are more interested in product history, seek to further understand about the ingredients and their production, seek knowledge regarding tasting and harmonization, as well as feeling pleasure in sharing the product, sharing information, and attracting new consumers (Beltramelli, 2015; Morado, 2017).

Against this background, the following question emerges: what are the identity profiles of craft beer lovers that can be determined from their drinking practices? Furthermore, this research is justified since the expanding market presents itself as a fertile arena for the realization of strategies and tactics in the relationship between brands and consumers, providing new opportunities for the organizations of the sector, through the creation of strategies based on the suggested profiles. Moreover, the need to broaden the central behaviorist approach to consumer research is considered (Rocha \& Barros, 2006). According to the authors, when considering consumption as an economic and individual practice, one fails to study the symbolic distinctions existing in the act, which devalues the entire current complex cultural system of society.

This present research enriches the consumer culture literature, predominantly combined with interpretive techniques (Gaião, Souza, \& Leão, 2012) and modestly explored in Brazil (Sampaio \& Perin, 2006), as it suggests the existence of a consumer culture related to craft beer through the typology of identity profiles. In regard to management, it serves as an inspiration for business strategies, as it is possible to identify and consistently communicate values that connect each consumer profile with the product. The present study also allows managers to understand consumers' perceptions regarding the product category, as well as allow for a greater conception of craft beer-related consumer culture, which may help to understand consumer loyalty. Finally, the identities suggested by the present study can serve as a segmentation mechanism that can be used by industry organizations in the search for relationship strategies with the target audience. 


\section{CONSUMER CULTURE THEORY (CCT)}

The Consumer Culture Theory (CCT) proposes a new perspective for the act of consumption, which was previously analyzed from an economic and utilitarian perspective, it is now understood through a cultural approach, the logic of freedom, in which it is understood as a symbolic act (Gaião, Souza, \& Leão, 2012). CCT sees consumption as a cultural phenomenon, differently from the psychological or economic perspective, with respect to a set of theoretical aspects that analyze the dynamic connection between consumer attitudes, the market and cultural meanings (Arnould \& Thompson, 2005).

Knowing that the CCT is not uniform, and that it resembles a family of interests and theoretical aspects that share a similar research orientation, Arnould and Thompson (2005) listed four major themes that moderate research in this area: Identity Projects of the consumer; Social and historical patterns of consumption; Market ideologies mediated by mass media; and Market Cultures. According to Arnould and Thompson (2005), projects of consumer identity bring together studies that seek to understand how the consumer makes choices, moderated by the market, and the identity characteristics they aim to establish and represent. CCT seeks to understand the forms of co-constitution and co-production in which individuals, in contact with market-generated products, forge a coherent, diverse or even fragmented sense of self.

Thus, identity can be understood as an individual or collective nucleus inserted within a cultural scheme of meanings (Woodward, 2009; Hall, 2006). Consumption operates in this dynamic as a relevant elaborator of meanings in the constitution of identities (Diniz \& Silva, 2017). It is noteworthy that in this study there is another thematic group proposed by Arnould and Thompson (2005) called "market culture", which investigates how some products and experiences can unite groups in types of consumer cultures or subcultures. This line of CCT research is focused on how consumers forge feelings of social ties and create distinct, fragmented cultural universes chosen through common consumer interests (Schouten \& McAlexander, 1995; Kozinets, 2001).

\subsection{Consumer Cultures}

A consumer subculture is understood as a diverse subgroup from a society that self-selects based on a shared commitment to a consumer activity, a brand, or even a product class (Schouten $\&$ McAlexander, 1995). For the authors, a subculture encompasses an identifiable hierarchical framework, a unique ethos (set of attitudes, beliefs and values) as well as unique rituals, language and modes of symbolic expression. Such a conceptualization is similar to the conceptualization of market culture presented by Arnould and Thompson (2005), in which consumers develop feelings of social solidarity and conceive distinct, fragmented, and self-selected cultural environments through the search for similar consumer preferences.

Concerning the use of certain CCT terms, Kozinets (2001) follows the understanding of a movement of authors, such as Thornton (2018), who criticize the use of the expression 'subculture', because the term can be understood as a subaltern culture which is dependent on a dominant culture. The author then recommends using the term consumer culture to conceptualize a related set of commercially produced images, texts, and objects that groups use, through the construction of overlapping, or even contradictory, practices, identities and meanings to guide experiences and the lives of its members.

Thus, these groups will somehow influence their consumption attitudes (Solomon, 2010), as they will be used as inspiration or comparison by the individual, and therefore are also known as reference groups. In this sense, Oliveira, Silva and Gaião (2018) identified the existence of a consumer community based around the content published in a social network. From this 
perspective, it is demonstrated that it is possible that a shared ethos emerges based on a specific market culture. The moment a reference group is created based on a brand or product, there is the birth of what is understood as the brand community (Dholakia, Blazevic, \& Wiertz, 2009).

The term brand community has numerous definitions: as a consumer community that shares a set of social bonds based on use or interest in a product (Maffesoli, 1996; Muñiz Jr., \& Schau, 2005); as a group that has, as its foundation, a set of individual bonds between brand owners and the psychological bond they have with the brand itself, the goods or service used, and with the organization (McAlexander, Schouten, \& Koenig, 2002). For Cova and Pace (2007), a brand community is constituted of a collective of people who share an affinity for a specific brand or product, and conceive a parallel universe with their own beliefs, rituals, values, languages, vocabulary and hierarchy.

\subsection{Consumer Identity}

Individual identity concerns the constitution of self-conception, which are the perceptions of self throughout one's life (Machado, 2003; Solomon, 2010). In this way, goods can determine the entire lifestyle of the individual who owns them, so in many instances they can be considered as an extension of the individual self, which demonstrates the relevance of objects contracted through the intermediary of consumption to the conception of identity (Belk, 1988). This discussion of the extension of the self of individuals presents contributions to consumer culture and can be used in a certain way as a paradigm for research in all the different fields of study in marketing (Ladik, Carrillat \& Tadajewski, 2015).

Thus, the act of consuming encompasses an individual's commitment to reveal her/himself to the other, in other words, to be noticed, perceived, and desired by other individuals (Bauman, 2005). In this sense, consumption is considered an indispensable element in the process of social representation, which turns consumption into a cultural entity (Barbosa \& Campbell, 2006). Consumption is, in this way, the mechanism of objectification and instrumentalization of social bonds, being at the core of these relations, interceded by habits and practices of consumption, through which individuals create their identities (Bauman, 2005), or even suffer deformations in their identity (Compeau, 2017).

Douglas and Isherwood (2006) state that in society, consumption is active: it creates values, structures identities, directs social relations and thus defines cultural representations. Assets acquired by a particular group or individual are tied to values, which proclaim categories, cultivate ideas, support lifestyles, instigate change, or create permanence. McCracken (2003) says that consumer goods carry cultural meanings. Additionally, Barbosa and Campbell (2006) state that consumption and culture are two connected entities insofar as the process of choosing a product or service takes place within a characteristic cultural plane. This fact can be observed in a globallocal relationship (Batra \& Wu, 2019; Strizhakova \& Coulter, 2019).

Thus, the act of consuming is an indicator through which social relations are explained, since it enables us to classify things, people, products, and groups of individuals. Society uses consumer goods for its physical and social representation. Goods are also consumed, however, to mediate social relations, providing status, establishing identities, and thus creating boundaries between groups of individuals (Barbosa \& Campbell 2006; Douglas \& Isherwood, 2006). Identities can be delineated from market cultures that constitute consumer cultures. From this perspective, the present research presents contributions from elements identified from reality. 


\section{RESEARCH METHOD}

The research seeks to understand the cultural identities based on the consumption of craft beers in the city of Fortaleza. To this end, it is defined as a basic qualitative research since it seeks to perceive the social world constructed from reality (Godoy, 2005). Semi-structured interviews and participant observations were selected as data collection techniques. This was possible since one of the researchers is involved with the beer scene in the city of Fortaleza, which is in line with the proposal of Mattar (2014), stating that the experience, knowledge, and sensitivity of the researcher are fundamental for the correct determination of which instrument will be best suited for each specific research.

For the selection of respondents, the criterion used was the consumption of craft beers at least once per month in the six months prior to the survey. It is believed that the monthly consumption of craft beers, in the frequency and period stipulated, characterizes the habit of periodic consumption of this product, thus excluding more occasional consumers of the beverage. The individual interviews enabled a direct communication, in which the researcher created a twoway conversation from which s/he collected the information related to the researched theme. This technique has the advantage of being flexible in that it can adapt or change course throughout the process, should the interviewer come across new discoveries or facts of real importance to the desired outcome.

The research corpus was constituted of two distinct stages. In this study, the subjects surveyed were consumers of craft beers, male and female, over eighteen years old, living in the city of Fortaleza. Thirty-two interviews ( 23 men and 9 women) were conducted in the field between June and July 2017, with an average duration of thirteen minutes and a total of seven hours recorded. To select the respondents, we used the snowball technique (Biernack \& Waldorf, 1981), through recommendations of people close to the researcher, who work in the craft beer business in Fortaleza. The analysis of the sociodemographic profile showed that the corpus was constituted of individuals with different occupations, such as liberal professionals, civil servants, and business owners. You can also see the presence of brewing professionals, such as shop owners, brewery owners, beer sommeliers, and master brewers.

Subsequently, in the second stage, after the identification of the initial profiles, surveys took place between September and October 2018 and were the method used to look for new evidence that these profiles effectively represent the consumer culture studied. The selection was also made through the snowball technique, and 23 interviews were conducted. Similar to what happened in the first stage of the research, there were five hours of interviews recorded, each with an average of thirteen minutes. Regarding the gender of respondents, the majority of respondents were male, totaling 23 men, with only 9 women being interviewed. As in the first research, it is noted from an analysis of the sociodemographic profile that the corpus was also composed of people from various occupations, including the presence of professionals from the beer sector.

In view of the subjectivity and complexity of the researched theme, the interviews were conducted using an interview script based on the literature we researched. The script was made up of a series of questions and aspects / factors that were initially considered to be covered throughout the process of identity construction. Therefore, questions were asked that range from motivations, beliefs, attitudes and habits, to feelings that encompass the research theme. The data collection took place in an unrestricted environment, usually the brewery context itself, through which the researcher encouraged the interviewee to talk about a specific subject, sharing as much data as possible, and exposing characteristics related to their identity profile. 
BBR

17

386

Participant observation took place during September and October 2018 at various craft beer establishments and events. In order to capture a variety of situations that would not have been accessible through questions to craft beer lovers, a script was prepared to describe what was observed in the research. It is worth mentioning that this research stage occurred after the previous definition of profiles resulting from the first stage. During a total of twenty-five hours of observation a field diary was used for records. By maintaining the field diary, self-discipline was needed for systematically observing and annotating the context and relationships inherent to craft beer consumers.

The observation script, similar to that defined for the interview script, aimed to observe aspects of identity related to the consumption of craft beers. Consideration was given to aspects such as the existence of some kind of influence of other consumers in the choice of beer consumed, purchase and consumption rituals, body language observed when the consumer liked or disliked the consumed beer, how the choice was made of the consumed beer, with whom they preferred to enjoy craft beer, if there was any prejudice among types of craft beer consumers, and likewise if there was any kind of hierarchy among consumers. The observation of these elements helped to understand the final identity profiles.

The procedure for analysis was performed using the content analysis technique (Bardin, 2009) for the treatment and interpretation of data obtained during the study. The interviews were recorded and transcribed. Participant observation was represented by field diaries, which resulted in the constitution of the documentary corpus to be analyzed. A floating reading of the material was performed, establishing a code for each of the interviews, in order to preserve the identity of the interviewed individuals. It is noteworthy that for the present study, the inspiration a priori was the categorization of profiles proposed by Lane et al. (2013), but a posteriori, additional insights regarding the craft beer consumer were observed that contributed to the formulation of profiles more specific to the product category, thus suggesting the existence of profiles concerning the craft beer consumers in the city of Fortaleza.

In regard to the quality criteria in the research, the following validity and reliability criteria were adopted for this study: triangulation of collection techniques, clarity of procedures and transfer, rich and detailed description and confirmation through analysis of data from interviews in the qualitative research, which was performed according to the decoded explanatory categories of the transcribed themes. Regarding the ethical questions of the research, there was an explanation of the research for the participants. Thus, the subjects had the choice to voluntarily adhere (by means of consent), or not, to the interviews, while being aware of the nature of the study and the obligations involved in it. In order to preserve the identity of the interviewees, each participant was represented by an identification code.

\section{FINDINGS}

Brazil is one of the largest beer consuming countries on the planet. The annual average of liters of beer consumed per inhabitant increases each year. According to the Brazilian Association of Craft Beer (ABRACERVA), beer is the favorite alcoholic beverage of two thirds of Brazilians for celebrations, with a preference of 64\%. The Brewer's Association (2018) defines craft breweries based on three criteria: the brewery should be small (less than six million barrels of beer per year), independent (not owned by an alcoholic beverage company) and the beers follow a tradition for innovative ingredients in the beer production. Data released by the Ministry of Agriculture, 
Livestock and Supply (MAPA, 2018) indicate a growth of approximately 19\% in the number of craft breweries registered in Brazil in 2018, the equivalent of 835, when in 2017 there were only 679 breweries.

\subsection{Product Involvement}

As a way to better characterize the identity profiles, it is should be shown how those involved interact with the consumed product. Based on the answers obtained, the involvement with the product can be divided into three different types. The first would be the professional, in which respondents say that their relationship with craft beer started because of their interest in working with the product, whether in the productive sector, in the sommelier sector, or in the commercial sector. The second type of involvement is related to the idea of the product as a hobby, either through consumption, or through home production. The third type of involvement concerns emotional involvement with the consumer good. It can be seen that some interviewees externalized feelings to express their involvement with craft beers.

It is important to add that through responses, and participant observation, it is clear that the beginning of engagement with the product came through referrals from friends. In addition, it was noted the existence of advocates of the product, those whose advocacy in favor of craft beer was fundamental to create enthusiasm and attract new consumers, which collaborates with the understanding of Brodie, Ilic, Juric and Hollebeek (2011). In addition, beer groups have been found in the city that serve as market catalysts influencing and forming new consumers, which corroborates with the understanding that human beings are social beings by nature, and it is natural to want to adapt to stipulated standards, and through this a group is conceived, being made up of individuals who want to fit in and identify with other individuals through a social bond (Solomon, 2010).

\subsection{Motivation of Consumption}

This research also addressed the motivations that led respondents to start and continue to drink craft beer. According to Vivek (2009), the motivation for consumption, which can be considered personal or social, is associated with the values that the consumer aspires to when involved in an initiative. The first consumer motivation to be analyzed is associated with experience. Based on the excerpts related to the theme identified during the interview, as well as after several hours of observation, it is possible to state that the experience is divided into two parts, the experience of sensory pleasure that is linked to the tasted flavors, and the experience of discovery, which is related to the fact of coming across something unheard of, different from what the market already offers.

The second motivation is learning, as respondents show interest in studying and learning more about the history, the ingredients, the various styles, and so on. According to Brodie et al. (2011), learning is characterized by indirect acquisition of cognitive skills that the consumer applies in the acquisition of a consumer good, or even during the decision-making process. Finally, the third motivation is related to social interest. While some consumers are interested in transactional and functional relationships, others seek experiential relationships with other consumers (Vivek, 2009). That being said, the third motivation is related to social interest, with the feeling of belonging to a group that shares affinities, this motivation demonstrates an important element, being the need for recognition as a member of a culture. It is noteworthy that the motivations are not exclusive, that is, the individual remains motivated to consume craft beer not only for one motivation, but also for the group of motivations together. 


\subsection{Identity Profiling}

The first research aimed to suggest cultural identities built through the consumption of craft beers in the city of Fortaleza. In this study, it was possible to distinguish the identities of participants involved in the activity of craft beer from beginners to more expert consumers of the product, based on their level of knowledge and their consumption habits, these being differentiating aspects suggested from the theory of Schouten and McAlexander (1995). To clarify the distinction of each profile and also to structure them, identities were categorized into the following subgroups: Beginners, Adventurer, Enthusiasts, Experts and Beer Snob.

The second research was based on research on market cultures (Arnould \& Thompson, 2005), consumer subcultures (Schouten \& McAlexander, 1995), consumer cultures (Kozinets, 2001), as well as studies on projects of consumer identity and the structuring influence of the market, in which the works of Belk (1988), Hearn (2008), Therkelsen and Gram (2008) stand out, in the constitution of consumer identity profiles belonging to the craft beer consumption culture in Fortaleza. Given the data obtained, it was possible to develop a typology of craft beer consumer profiles based on the multidimensional perspective of engagement (see Brodie et al., 2011), establishing five typologies for the studied consumer profiles, namely: Beginner, Adventurer, Beer Evangelist, Expert and the Beer Snob.

The typographies selected above were inspired by the research called Craft Beer and Consumer Behavior (Lane et al., 2013), which focuses on the behavior of craft beer consumers in the US state of Colorado, where, at the time of the research, there were more than 160 established craft breweries, allowing for the opportunity to fully observe and experience craft beer culture. Through research, two primary consumer market segments were discovered, the "expert" and the "novice" craft beer drinker. However, additional insights were observed regarding these two segments that contribute to more robust profiles, thus determining the existence of further profiles as previously mentioned. Chart 1 presents the characteristics of each profile and excerpts that justify them.

Both surveys suggested the existence of the novice consumer, which describes the public who are in the introductory stage of craft beer consumption. The novice consumer is the beginner, in the midst of a transition from the consumption of mainstream beers and tentatively beginning to get to know the new flavors and possibilities of craft beers. Research has also pointed out that the gateway to the craft beer universe is most commonly the lighter and sweeter styles, which are closer in flavor to the normal beers. In both surveys it was found that this consumer still does not know the distinction, or is not concerned with making a distinction, between each of the styles, but looks for a higher quality beer that pleases the taste, regardless of the type of glass, the service temperature, or harmonizations. Due to their short time as consumers of craft beers, their drinking habit is still related to mainstream beers.

Based on the information collected in the surveys, it was suggested that there is a consumer profile that seeks to explore more diverse styles of beer. In the first survey s/he was identified as an explorer and in the second survey as an adventurer. The sense of discovery and curiosity are prevalent in these profiles, which regardless of quality, are attracted much more by the possibility of experiencing and discovering new sensations and experiences - they enjoy discovering something new, then showing loyalty to the product, but not showing brand or style loyalty. 
Chart 1

Constitution of Identity Profiles

\begin{tabular}{|c|c|c|c|}
\hline Identity Profile & Characteristics & Study 1 & Study 2 \\
\hline \multirow{4}{*}{ Beginner } & $\begin{array}{l}\text { Consumer } \\
\text { in transition }\end{array}$ & $\begin{array}{l}\text { "I was introduced to a weizenbier } \\
\text { by a friend, found it amazing and } \\
\text { wanted to know more. I started } \\
\text { to notice more the beers that were } \\
\text { on the corner of the supermarket } \\
\text { shelf."(E13). } \\
\text { "I already liked beer and I tried new } \\
\text { labels according to their appearance } \\
\text { in the market." (E9) }\end{array}$ & $\begin{array}{l}\text { "There is the consumer who is at } \\
\text { the beginning of their career, who } \\
\text { is leaving the industrialized beers, } \\
\text { so he looks for beers similar to } \\
\text { industrialized beers." (E38) } \\
\text { "There are people who are starting } \\
\text { to drink good beers and also drink } \\
\text { regular beers, that's all." (E37) }\end{array}$ \\
\hline & $\begin{array}{l}\text { Little } \\
\text { knowledge }\end{array}$ & $\begin{array}{l}\text { "To tell the truth I still don't know } \\
\text { how to consume, I'm still learning, } \\
\text { but I still like it cold." (E3). } \\
\text { "There are those who are just } \\
\text { beginning, they have little } \\
\text { knowledge, and usually only drink a } \\
\text { specific style" (E20) }\end{array}$ & $\begin{array}{l}\text { "I consider myself to be an } \\
\text { apprentice of the product because it } \\
\text { has been a short time that I've been } \\
\text { involved with beer or any beverage." } \\
\text { (E32) } \\
\text { "I'm kind of a baby, I'm a zygote } \\
\text { actually, I'm not even a beginner." } \\
\text { (E36) }\end{array}$ \\
\hline & $\begin{array}{l}\text { Ignorance } \\
\text { of consumer } \\
\text { practices }\end{array}$ & $\begin{array}{l}\text { "Nothing specific. I only try to } \\
\text { keep beers that are special and } \\
\text { recommended for this purpose."(E4) } \\
\text { "No ritual, at the most one photo" } \\
\text { (E16) }\end{array}$ & $\begin{array}{l}\text { "No, I don't have any protocol." } \\
\text { (E47) } \\
\text { "No, I'm starting to take more risks } \\
\text { in the harmonization, but I don't } \\
\text { have a definite habit." (E52) }\end{array}$ \\
\hline & $\begin{array}{l}\text { Low product } \\
\text { loyalty / High } \\
\text { brand and } \\
\text { style loyalty }\end{array}$ & $\begin{array}{l}\text { "Yes. I'm an unconditional fan of } \\
\text { wheat beers."(E7) } \\
\text { "My refrigerator can't be without a } \\
\text { witbier." (E5) }\end{array}$ & $\begin{array}{l}\text { "So, I have my favorite brewery, I } \\
\text { repeat, I repeat the beers I like a lot, } \\
\text { but, what I do most is repeat the } \\
\text { beer I like." (E34) }\end{array}$ \\
\hline \multirow{3}{*}{ Adventurer } & $\begin{array}{l}\text { Avid consumer } \\
\text { of discovery }\end{array}$ & $\begin{array}{l}\text { "No, I like all styles because each one } \\
\text { seeks to offer consumers different } \\
\text { tastes and flavors."(E27) } \\
\text { "No, I like to try different styles, I } \\
\text { think it's part of the fun to know } \\
\text { different styles and brands." (E12) }\end{array}$ & $\begin{array}{l}\text { "There is always one who is } \\
\text { desperate to try everything." (E38) } \\
\text { "It's that guy who has been } \\
\text { introduced to the craft beer world } \\
\text { and tries to explore different things, } \\
\text { tries to look for new labels." (E51) }\end{array}$ \\
\hline & $\begin{array}{l}\text { Disinterest } \\
\text { in consumer } \\
\text { practices }\end{array}$ & $\begin{array}{l}\text { "I have no specific ritual. But if I } \\
\text { come across many options, I usually } \\
\text { take a long time to choose."(E5) } \\
\text { "Nothing specific. I only try } \\
\text { to keep beers that are special } \\
\text { and recommended for this } \\
\text { purpose."(E23) }\end{array}$ & $\begin{array}{l}\text { "I don't have it, I like to drink." } \\
\text { (E46) } \\
\text { "No, I'm starting to take more risks } \\
\text { in the harmonization, but I don't } \\
\text { have a definite habit." (E52) }\end{array}$ \\
\hline & $\begin{array}{l}\text { High product } \\
\text { loyalty and } \\
\text { low brand and } \\
\text { style loyalty }\end{array}$ & $\begin{array}{l}\text { "I have my preferences, but I drink } \\
\text { everything. I think it's important } \\
\text { to know the styles and their } \\
\text { formulations."(E31) } \\
\text { "I don't think about loyalty. I don't } \\
\text { have a favorite style. I like a lot of } \\
\text { things." (E17) }\end{array}$ & $\begin{array}{l}\text { "I think that to stick to a brand, to } \\
\text { a style, is to miss out on the best } \\
\text { of beer, which is the question of } \\
\text { variety, this infinite possibility of } \\
\text { experience." (E33) }\end{array}$ \\
\hline
\end{tabular}


BBR

17

390
Chart 1

Cont.

\begin{tabular}{|c|c|c|c|}
\hline Identity Profile & Characteristics & Study 1 & Study 2 \\
\hline \multirow{3}{*}{$\begin{array}{l}\text { Enthusiast or } \\
\text { Beer Evangelist }\end{array}$} & $\begin{array}{l}\text { Enthusiast } \\
\text { of the beer } \\
\text { culture }\end{array}$ & $\begin{array}{l}\text { "Usually I usually record what I } \\
\text { am consuming and share on social } \\
\text { networks." (E21). } \\
\text { "I feel enthusiastic about getting } \\
\text { other people into the craft market." } \\
\text { (E2) }\end{array}$ & $\begin{array}{l}\text { "I want these people to discover } \\
\text { a new world, to have the same } \\
\text { experiences I had, it's like I want to } \\
\text { convert these people into the world } \\
\text { of good beers." (E38) }\end{array}$ \\
\hline & $\begin{array}{l}\text { Need to be } \\
\text { recognized } \\
\text { as a consumer }\end{array}$ & $\begin{array}{l}\text { "As someone who is not afraid of } \\
\text { the new and has many good stories } \\
\text { and indications to share. I love } \\
\text { recommending people things like } \\
\text { music, books and beers. I feel useful, } \\
\text { helpful and smarter."(E26). }\end{array}$ & $\begin{array}{l}\text { "Well, knowledge is critical for } \\
\text { you to influence someone, and } \\
\text { the feeling is gratitude, you feel } \\
\text { high, you feel, as I would say, good } \\
\text { and more interesting, I feel more } \\
\text { important." (E45) }\end{array}$ \\
\hline & $\begin{array}{l}\text { Beer is part of } \\
\text { your lifestyle }\end{array}$ & $\begin{array}{l}\text { "My house is full of decorations } \\
\text { based around beer, even my dog has a } \\
\text { beer name" (E2) }\end{array}$ & $\begin{array}{l}\text { "If having many beer themed shirts } \\
\text { and caps, having a dog named after } \\
\text { a beer, having a home decorated } \\
\text { with items, going to themed events } \\
\text { and having drunk over a thousand } \\
\text { beers is being a fan, then I am." } \\
\text { (E48) }\end{array}$ \\
\hline \multirow{3}{*}{ Expert } & $\begin{array}{l}\text { Knowledgeable } \\
\text { about the } \\
\text { product }\end{array}$ & $\begin{array}{l}\text { "As a professional in the field, I have } \\
\text { a lot of knowledge on the subject." } \\
\text { (E15). } \\
\text { "It's been ten years dedicated to the } \\
\text { study of beer, although I'm not a } \\
\text { sommelier, I have a vast knowledge, I } \\
\text { even make homemade beer." (E6) }\end{array}$ & $\begin{array}{l}\text { "Yes, I have some knowledge, after } \\
\text { four years reading about it, I took } \\
\text { some basic courses, and tasted a } \\
\text { lot of labels, but I still have a lot to } \\
\text { learn and try." (E35) } \\
\text { "Yes, so, I consider myself a product } \\
\text { expert because I took a sommelier } \\
\text { course, I have already been working } \\
\text { three years in this area, so I already } \\
\text { have a good foundation." (E44) }\end{array}$ \\
\hline & $\begin{array}{l}\text { They are } \\
\text { regarded } \\
\text { as opinion } \\
\text { makers }\end{array}$ & $\begin{array}{l}\text { "There are simple consumers with no } \\
\text { interest in studying, and advanced } \\
\text { scholars, who end up teaching a lot } \\
\text { of people." (E22) } \\
\text { "I like to learn from those who really } \\
\text { know about beer." (E18) }\end{array}$ & $\begin{array}{l}\text { "Sometimes I find that people who } \\
\text { have been drinking longer, as well as } \\
\text { in regard to who drinks wine, they } \\
\text { have a certain aura, as if they were } \\
\text { opinion makers for the beginner." } \\
\text { (E43) }\end{array}$ \\
\hline & $\begin{array}{l}\text { Knowledgeable } \\
\text { about } \\
\text { consumer } \\
\text { practices } \\
\text { and rituals }\end{array}$ & $\begin{array}{l}\text { "I pour, appreciate its color, smell } \\
\text { it deeply and then take the first } \\
\text { generous drink so that all my taste } \\
\text { buds can appreciate it and the } \\
\text { intensity of the experience is as great } \\
\text { as possible."(E1) } \\
\text { "From label and shelf life analysis to } \\
\text { cooling, serving and environment } \\
\text { everything is done with care." (E28) }\end{array}$ & $\begin{array}{l}\text { "I always try to see if it is fresh, well } \\
\text { stored at the time of purchase, and } \\
\text { at the time of consumption, I try to } \\
\text { do a basic tasting routine trying to } \\
\text { observe the characteristics of beer, } \\
\text { I try not to be biased by comments } \\
\text { from other colleagues and I always } \\
\text { try to look at the positive side in } \\
\text { relation to its defects."(E51) }\end{array}$ \\
\hline
\end{tabular}


Chart 1

Cont.

\begin{tabular}{|c|c|c|c|}
\hline Identity Profile & Characteristics & Study 1 & Study 2 \\
\hline \multirow{3}{*}{ Beer Snob } & $\begin{array}{l}\text { Disliked } \\
\text { among other } \\
\text { consumers }\end{array}$ & $\begin{array}{l}\text { "The type who does not know } \\
\text { and arrives boasting, not trying } \\
\text { to understand the rules of certain } \\
\text { places and comes full of themselves } \\
\text { or wanting to understand more than } \\
\text { everyone else already there." (E4) }\end{array}$ & $\begin{array}{l}\text { "There are those who really know } \\
\text { and there are those who pretend to } \\
\text { know just to look good." (E48) }\end{array}$ \\
\hline & $\begin{array}{l}\text { Tries to } \\
\text { enforce rules }\end{array}$ & $\begin{array}{l}\text { "I realized that a (small) part want } \\
\text { to make a fuss, impose unimportant } \\
\text { rules. Luckily they are only a few." } \\
\text { (E09) } \\
\text { The guy who thinks he knows a lot } \\
\text { and ends up talking bullshit. (E29) }\end{array}$ & $\begin{array}{l}\text { [During a Bottle Share at Hey } \\
\text { Ho Specialty Bar] The evening } \\
\text { continued with information } \\
\text { exchange and good humor, until } \\
\text { at the end, I remember one of the } \\
\text { participants who had not liked } \\
\text { the selection said that at the next } \\
\text { meeting they should bring better } \\
\text { beers because otherwise it wouldn't } \\
\text { be worth it to make available the } \\
\text { beers he had for the event. (Daily } \\
\text { Participant Observation) }\end{array}$ \\
\hline & $\begin{array}{l}\text { The need } \\
\text { to show } \\
\text { superiority } \\
\text { through } \\
\text { consumption }\end{array}$ & $\begin{array}{l}\text { "Yes, the beer snob, just to say he } \\
\text { has money, he has a collection with } \\
\text { a thousand labels, they buy liters. In } \\
\text { fact, this guy doesn't even appreciate } \\
\text { it, he's just passing in real life and on } \\
\text { social networks."(E17) } \\
\text { "There are people who appreciate it, } \\
\text { and people who drink to say they } \\
\text { have money (status)." (E14) }\end{array}$ & $\begin{array}{l}\text { "But unfortunately there is that } \\
\text { boring guy who thinks he's better } \\
\text { than you because he drinks rare or } \\
\text { more expensive beers, and wrinkles } \\
\text { his nose at the label you're drinking, } \\
\text { unfortunately human beings are like } \\
\text { that, it's not the fault of beer." (E35) }\end{array}$ \\
\hline
\end{tabular}

Source: Research data (2019).

The Enthusiast was identified as the Beer Evangelist in the second survey. It is a profile who enjoys directing and influencing others in the enjoyment of craft beer, they do not recognize themselves as an authority on the subject, but often recommend to and educate other profiles, and enjoy the social aspect and lifestyle that craft beer provides. The Beer Evangelist has the desire to be identified and defined by the craft beer culture, this profile feels the need to be recognized as a craft beer consumer. Beer is part of their lifestyle, through the collection of glasses, beer mats, clothing, home décor and even tattoos, some even giving their pets the name of beer styles or brands. Another inherent aspect of the Beer Evangelist is their need to share their experiences with other individuals, as noted during the research.

The Expert is the profile that holds the highest degree of knowledge about craft beer, its science, and its culture. They are extremely careful in choosing brands, taking into consideration brewery, style, and validity. They are very attentive to the served temperature, the most appropriate glass and, where possible, to harmonization with dishes. They follow a tasting technique in which they examine appearance, aroma, taste, texture in the mouth, and defects. They are viewed by the consumer community as leaders. Like the Beer Evangelists, the Experts demonstrate a need for recognition and notoriety. Some like to be seen as opinion makers, and many even create blogs or social media profiles to share their experiences, perform brand evaluation and recommendations, 
as well as advice on harmonization. Others work in the area, such as sommeliers, consultants, and/or teachers.

Finally, there is the Beer Snob, a neologism that is derived from wine bore, who is the subject who thinks s/he is an expert on wines and adopts a professional and pretentious air to talk about the drink (Beltramelli, 2015). This typology, also often referred to as a arrogant, refers to a negative consumer profile within the brewing community. The profile may have characteristics of all the previous profiles, but is inconvenient, not knowing how to behave properly towards other consumers, often causing embarrassment, as reported by some of the interviewees. When drinking with others, they like to impose their taste and believe that their opinion is correct. Finally, the Beer Snob identifies with a feeling of obsession with the product, which manifests itself through the need to appear and be superior to other consumers.

\subsection{Feelings particular to each profile tyipe}

Still in regard to the research, the existence of certain feelings particular to each type of profile was also identified. The Beginner profile demonstrated a feeling that was a mixture between curiosity and distrust, manifested through the concern about the product. The Explorer or Adventurer maintains a sense of curiosity, but combined with anxiety, manifested in the need to find new flavors and taste as many brands as possible, and see themselves through their consumption as avant-garde. For the Enthusiast, or Beer Evangelist, the feeling of joy was visible, this manifests itself through happiness from discovering new flavors and sharing their knowledge with others, they want to be identified and defined by the beer culture, they see themselves through their consumption as people who are in demand.

In the case of Expert, the feeling is one of love for craft beer, they want to be identified and defined as knowledgeable about beer culture, and see themselves through their consumption as educated and opinion-forming. Finally, the Beer Snob identified with a feeling of obsession with the product, which manifests itself through the need to appear and be superior to other consumers. Thus, based on the analyzes performed above, the following research understands and demonstrates how consumption influences the constitution of identity profiles of craft beer consumers.

\subsection{Craft beer-related Consumer culture}

Based on a study of consumers of Harley Davidson motorcycles and related products, Schouten and McAlexander (1995) defined consumer cultures as distinct groups of a self-selecting society which are based on a shared commitment to a specific type of product, brand, or activity through consumption. Through the information obtained in this research (see Chart 2), there is an identifiable hierarchical framework, a unique ethos (selection of shared beliefs and values), as well as rituals, language and unique modes of symbolic expression related to beer consumption, which according to Schouten and McAlexander (1995), are prerequisites that define a consumption culture. 
Chart 2

Craft beer-related consumer culture

\begin{tabular}{|c|c|c|}
\hline Prerequisites & Study 1 & Study 2 \\
\hline $\begin{array}{l}\text { Identifiable } \\
\text { hierarchical } \\
\text { framework }\end{array}$ & $\begin{array}{l}\text { "I believe there is a certain hierarchy, } \\
\text { at the top are the professionals, the } \\
\text { enthusiasts, then there are the people who } \\
\text { are learning, who are at the beginning." } \\
\text { E18 }\end{array}$ & $\begin{array}{l}\text { "So, I consider that the craft beer } \\
\text { audience is divided between the beginner, } \\
\text { the curious, one who tries to explore } \\
\text { different things, and has those who know } \\
\text { and study." E31 }\end{array}$ \\
\hline Unique ethos & $\begin{array}{l}\text { "Drink less, drink better" E11 } \\
\text { "Drink less, drink better / Drink Local / I } \\
\text { Believe In IPA / Come To The Stout Side" } \\
\text { E16 }\end{array}$ & $\begin{array}{l}\text { "Drink less, drink better is very common. } \\
\text { There is also drink local, others talk a lot } \\
\text { about beer made from corn." E35 } \\
\text { "The craft beer consumer believes that } \\
\text { only craft beer has value." E37 }\end{array}$ \\
\hline $\begin{array}{l}\text { Rituals, language } \\
\text { and unique modes of } \\
\text { symbolic expression }\end{array}$ & $\begin{array}{l}\text { "At the time of consumption I follow the } \\
\text { tasting booklet (smell, taste, aftertaste). I } \\
\text { see the styles, quantity, values, who made } \\
\text { it." E8 } \\
\text { "I find the aroma important, so I always } \\
\text { swirl the glass to release the aroma. I like } \\
\text { proper glasses whenever possible. The } \\
\text { correct temperature. I don't like it very } \\
\text { cold." E10 }\end{array}$ & $\begin{array}{l}\text { "The ritual is that I always try to drink } \\
\text { from the right glass or beer brand glass." } \\
\text { E41 } \\
\text { "At the time of purchase I first read the } \\
\text { label, see what the brewery is, whether } \\
\text { it is worth it or not, then take care of } \\
\text { the glass, temperature, harmonization. It } \\
\text { depends a lot on the day. If you are going } \\
\text { to drink more than one, you have to } \\
\text { follow an order of intensity." E49 }\end{array}$ \\
\hline
\end{tabular}

Source: Research Data (2019).

Through the information obtained, it was observed that there is the existence of an identifiable hierarchical framework, a unique ethos (selection of beliefs and shared values), as well as rituals, language and unique modes of symbolic expression related to beer consumption.

\section{DISCUSSION}

With regard to CCT, the present research observed the existence of an identifiable hierarchical framework, a unique ethos, as well as rituals, language and unique modes of symbolic expression related to craft beer consumption in the city of Fortaleza, which according to Schouten and McAlexander (1995) are prerequisites of a consumer culture. To reinforce this understanding, we also identified the three conditions proposed by Muniz Jr. and O'Guinn (2001) for a brand community to be established:

1. developed shared awareness: reflected in the bonds that craft beer consumers feel towards each other;

2. shared rituals and traditions: through the reproduction and internal and external transmission of meanings related to the culture of consuming craft beer; and

3. a sense of moral responsibility in the members' sense of duty towards the consumer culture and other craft beer consumers, being portrayed through the integration and retention of consumers.

We also identified the motivational factors related to craft beer consumption, which are: experience; learning; and social interests. The factors found are similar to those found in several studies which investigated the motivations of consumer engagement in a brand community, 
BBR

17

394

being: surveillance; personal relationship; personal identity; and fun. These similarities corroborate with the studies of Dholakia and Bagozzi (2004), Madupu and Cooley (2010a), and Kuo and Feng (2013).

The research also finds similarities with the study by Fox (1987), and Schouten and McAlexander (1995), where individuals from a branded community were hierarchized into hardcore or highstatus members and softcore members (Figure 1). The Beer Evangelist and Expert profiles were found to be related to the hardcore members of the study by Fox (1987) and Schouten and McAlexander (1995), as both function as opinion leaders within a consumer culture, demonstrating a commitment with the style and ideology of craft beer. On the other hand, softcore members, composed of prospective and probationary members, were present in both previous research and the present research at hand, having a less complete commitment to the styles and values related to the consumer culture, and whose roles are subordinated and dictated by hardcore members.

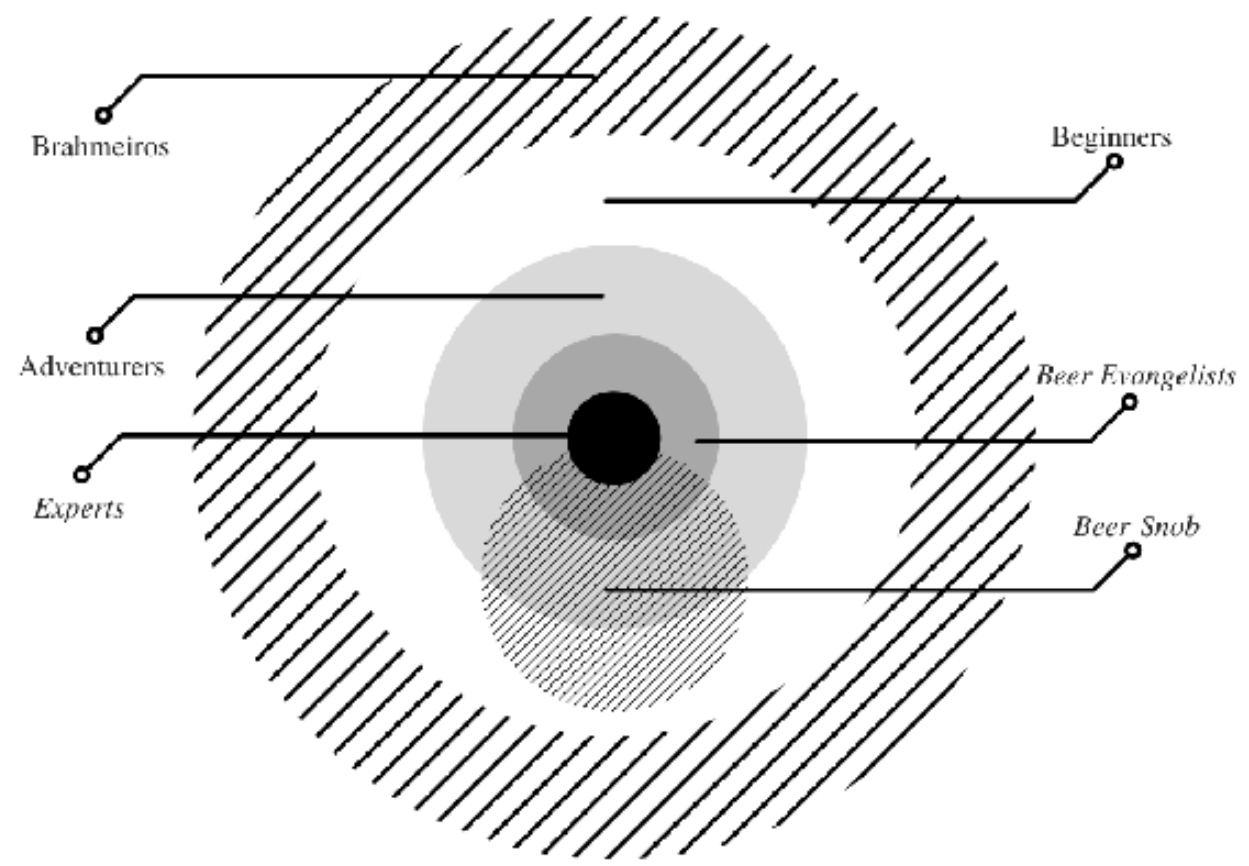

Figure 1. Hierarchical social structure.

Source: Research Data (2019).

Inspired by the proposal of Schouten and McAlexander (1995), which is based on Fox's concept of concentric circles (1987) to present the hierarchical social structure found in the Harley Davidson subculture, this research proposes a hierarchical social structure describing a brand community relating to craft beer in the city of Fortaleza (Figure 1), in which the smaller circle, located in the center of the structure, is known as hardcore, and represents the group of members intensely engaged with craft beer, and the larger circles are known as softcore, and concern members who have low engagement with the product studied. We noticed that the circle that represents the beer snob interacts with the other circles because it is understood that this profile represents distorted versions of the other profiles. A circle is necessary that represents consumers who are on the fringes of consumer culture, referred to in the following survey as "Brahmeiros", i.e., those who consume mainstream beer and only sometimes craft beer, and therefore do not postulate participation in the group. 
By elaborating a typology of craft beer consumer profiles, the present study collaborates with the understanding of Suarez, Galindo, Soukup Filho and Machado (2015) about heterogeneity among members. With regard to the existence of authentic and illegitimate members, the present research partially disagrees with the understanding of Bellezza and Kainan (2014). The authors characterized the illegitimate as outsiders, and divided them into two types: brand tourists and brand immigrants. Tourists are related to those who sometimes acquire brand products, but do not postulate membership in the group, while immigrants are related to those who claim to be part of the group in question and require this status. In the present study, only one type of outsider was identified, which was called "Brahmeiro" (mainstream beer consumer). Following Bellezza and Kainan (2014), one can observe characteristics in common with tourists and "Brahmeiros", however, the inherent aspects of immigrants in this research are similar not to an outsider, but to one of the members identified in the present research: the Beer Snob.

\section{CONCLUSION}

The act of consuming can be considered as a fundamental factor in the construction of the social identity of enthusiasts of craft beer. Thus, this research presents the elaboration of a typology of five profiles of craft beer consumers. That said, it is believed that this research has made significant contributions to the field of CCT, more specifically to the thematic group "identity projects", by understanding the characteristics of identity that the craft beer consumer wants to establish and represent, as well as the thematic group "market culture", by presenting elements that suggest the existence of a consumer culture related to craft beer.

From the managerial point of view, the results collaborate with the basis of market segmentation, by understanding the research paradigm in which different consumer profiles can relate to the product and to each other through it. Thus, the cultural identities related to craft beer consumers, suggested by this study, can serve as a segmentation mechanism, which can be employed by industry organizations in the search for relationship strategies with the target audience.

Some limitations may be indicated. The first refers to the lack of work in the national and international literature regarding the influence of consumption on the constitution of identity profiles of craft beer consumers. The second concerns the fact that most of the known craft beer works follow a view focused on a behaviorist approach, that is, they leave aside the whole complex cultural system and restrict themselves to analyzing consumption as an economic and individual fact, however, it is noteworthy that market segmentation surveys are quantitative in nature and therefore the results should be employed with discernment in developing segmentation strategies.

Suggestions for research are the possibility of a quantitative research, as well as adapting and applying this study to other categories of drinks, such as gourmet coffees, artisanal cachaça, etc. New studies on consumer cultures are expected to make use of these contributions and new aspects can be discovered that broaden the discussion by providing new insights into the field of culture and consumption. 


\section{REFERENCES}

17

Associação Brasileira de Cerveja Artesanal (2018). http://abracerva.com.br/. Acess: 12 Fevereiro 2018.

Arnould, E. J., \& Thompson, C. J. (2005). Consumer culture theory (CCT): twenty years of research. Journal of Consumer Research, 31(4), 868-882.

Bagozzi, R. P., \& Dholakia, U. M. (2006). Antecedents and purchase consequences of customer participation in small group brand communities. International Journal of Research in Marketing, 23(1), p. 45-61.

Barbosa, L., \& Campbell, C. (2006). Cultura, consumo e identidade. Rio de Janeiro: FGV.

Bardin, L. (2009). Análise de conteúdo. Lisboa: Ediçôes 70.

Barros, C. (2007). Trocas, hierarquia e mediação: as dimensóes culturais do consumo em um grupo de empregadas domésticas. Tese (Doutorado em Administração). Universidade Federal do Rio de Janeiro, Rio de Janeiro.

Batra, R., \& Wu, Y. (2019), “Comment on “Consumer cultural identity...”: global citizenship and reactance”, International Marketing Review, 36(5), 628-632. https://dx.doi.org/10.1108/IMR04-2019-0120

Bauman, Z. (2005). Identidade: entrevista a Benedetto Vecchi. Tradução de Carlos A. Medeiros - Rio de Janeiro: Jorge Zahar Editora.

Belk, R. W. (1988). Possessions and extended self. Journal of consumer research, 15(2), 139-168.

Bellezza, S.; Keinan, A. (2014) Brand Tourists: how Non-Core Users Enhance the Brand Image by Eliciting Pride. Journal of Consumer Research, 41, p. 397-417.

Beltramelli, M. (2015). Cervejas, brejas e birras: um guia completo para desmistificar a bebida mais popular do mundo (2a ed.). São Paulo: Leya.

Bhattacharya, C., \& Elsbach, K. (2002). Us versus them: The roles of organizational identification and disidentification in social marketing initiatives. Journal of Public Policy \& Marketing, 21(1), 26-36.

Biernacki, P., \& Waldorf, D. (1981). Snowball sampling: Problems and techniques of chain referral sampling. Sociological methods \& research, 10(2), 141-163.

Brewer's Association (2018). https://www.brewersassociation.org/.

Brodie, R J. Ilic, A., Juric, B., \& Hollebeek, L. (2011). Customer Engagement: Conceptual Domain, Fundamental Propositions, and Implications for Research. Journal of Service Research, 14(3), 252-271.

Compeau, L. (2017), “The Influence of Bad Credit on Consumers' Identities”. Qualitative Consumer Research. Review of Marketing Research, 14, 51-77. https://dx.doi.org/10.1108/S1548643520170000014006

Cova, B.; Pace, S., \& Park, D. J. (2007). Global brand communities across borders: The Warhammer case. International Marketing Review, 24(3), 313-329.

Dholakia, U.; Blazevic, V., \& Wiertz, C. (2009). Communal service delivery: how customers benefit from participation in firm-hosted virtual P3 communities. Journal of Service Research, 12(2), 208-226.

Diniz, J. M. A., \& Silva, M. E. (2017). Meu perfil de Facebook me representa! um estudo da relação entre feminismo e o eu estendido digital. Revista Alcance (Online), 24(3), 309-328.

Douglas, M., \& Isherwood, B. (2004). O mundo dos bens: para uma antropologia do consumo. Rio de Janeiro: UFRJ. 
Fox, K. J. (1987). Real Punks and Pretenders. Journal of Contemporary Ethnography, 16(3), 344-370,.

Füller, J.; Matzler, K., \& Hoppe, M. (2008). Brand community members as a source of innovation. Journal of Product Innovation Management, 25(6), 608-619.

Gaião, B. F. S., Souza, I. L., \& Leão, A. L. S. (2012). Consumer Culture Theory (CCT) Já É uma escola de pensamento em Marketing? Revista de Administração de Empresas, 52(3), 330-344.

Godoy, A. S. (2005). Refletindo sobre critérios de qualidade da pesquisa qualitativa. Revista Eletrônica de Gestão Organizacional, 3(2), 81-89.

Hall, S. A identidade cultural na pós-modernidade. Rio de Janeiro: DP\&A, 2006.

Hassay, D. N., \& Peloza, J. (2009). Building the Charity Brand Community. Journal of Nonprofit \& Public Sector Marketing, 21(1), 24-55.

Hearn, A. (2008) Meat, mask, burden: probing the contours of the branded self. Journal of Consumer Culture, 8(2), 197-217.

Kozinets, R. V. (2001). Utopian Enterprise: Articulating the Meaning of Star Trek's Culture of Consumption. Journal of Consumer Research, 28(1), 67-89.

Kuo, Y. F., \& Feng, L. H. (2013) Relationships among community interaction characteristics, perceived benefits, community commitment, and oppositional brand loyalty in online brand communities. International Journal of Information Management, 33(6), 948-962.

Ladik, D., Carrillat, F., \& Tadajewski, M. (2015), Belk's (1988) "Possessions and the extended self" revisited. Journal of Historical Research in Marketing, 7(2), 84-207. https://dx.doi.org/10.1108/ JHRM-06-2014-0018

Lane, V. R., Carpenter, A. J., Darlington, W., Frick, D., Garver, T., Kane, H. C., Mimken, R., \& Serwitz, K. (2013). Craft Beer and Consumer Behavior. https://anthonygarver.files.wordpress. com/2013/06/buyer-behavior-craft-beer-project.pdf

Machado, H. V. (2003). A Identidade e o Contexto Organizacional: Perspectivas de Análise. Revista de Administração Contemporânea, 7, 51-73.

Madupu, V., \& Cooley, D. O. (2010) Antecedents and Consequences of Online Brand Community Participation: A Conceptual Framework. Journal of Internet Commerce, 9(2), 127-147.

Maffesoli, M. (2006). O tempo das tribos: o declinio do individualismo nas sociedades pós-modernas. Rio de Janeiro: Forense Universitária.

MAPA - Ministério da Agricultura, Pecuária e Abastecimento (2018). http://www.agricultura.gov.br/

Mattar, F. N. (2014). Pesquisa de marketing: metodologia, planejamento, execução e análise. (7th ed.). São Paulo: Atlas.

McAlexander, J.,Schouten, J., \& Koenig, H. (2002). Building brand commuity. Journal of Marketing, 66(1), 38-54.

McCracken, G. (2003). Cultura e Consumo: novas abordagens ao caráter simbólico dos bens e das atividades de consumo. Rio de Janeiro: Mauad.

Morado, R. (2017). Larouse da cerveja. São Paulo: Alaúde.

Muniz Jr., A. M., \& O’Guinn, T. C. (2001). Brand Community. Journal of Consumer Research, 27(4), 412-432.

Muñiz, A. M. Jr.; Schau, H. J. (2005). Religiosity in the abandoned apple Newton brand community. Journal of Consumer Research, 31(4), 737-747. 
BBR

17

398

Oliveira, R. S., Silva, M. E., Gaião, B. F. S. (2018). Orgulho de ser nordestino! Um estudo sobre ethos compartilhado por seguidores em uma página do Facebook. Gestão.Org - Revista Eletrônica de Gestão Organizacional, 16(2), 182-193.

Sampaio, C. H., \& Perin, M. G. (2006). Pesquisa científica da área de marketing: uma revisão histórica. Revista de Administração Contemporânea, 10(2), 179-202.

Schau, h. J.; Muñiz Jr., A. M., \& Arnould, E. J. (2009). How brand community practices create value. Journal of marketing, 73(5), 30-51.

Schouten, J. W., \& McAlexander J. H. (1995). Subcultures of consumption: an ethnographic of the new bikers. Journal of Consumer Research, 22(1), 43-61.

Solomon, M.(2010). O Comportamento do Consumidor: Comprando, Possuindo e Sendo. (9th ed.). Porto Alegre: Bookman.

Strizhakova, Y., \& Coulter, R. (2019), "Consumer cultural identity: local and global cultural identities and measurement implications”, International Marketing Review, 36(5), 610-627. https://dx.doi. org/10.1108/IMR-11-2018-0320

Suarez, M. C., Galindo, F. L. O. C., Soukup Filho V., \& Machado, R. (2015). Constituição de uma Comunidade Virtual de Marca no Lançamento de Novo Produto. Revista de Administraçáo Contemporânea, 19, 117-136.

Therkelsen, A., \& Gram, M. (2008) The meaning of holiday consumption. Journal of Consumer Culture, 8(2), 269-292.

Thornton, S. (2018). Club Cultures. Music, Media and Subcultural Capita (4a ed.). Oxford: John Wiley \& Sons.

Vivek, S. D. (2009). A scale of consumer engagement (Doctoral dissertation, University of Alabama Libraries).

\section{AUTHOR'S CONTRIBUTION}

The first author was responsible for the idealization and accomplishment of the research. The second author supervised the research process and together with the third author developed the structure, review and submission of the article.

\section{ACKNOWLEDGEMENT}

We thank the Cearense Foundation for Supporting Scientific and Technological Development (FUNCAP) and the University of Fortaleza for the support provided for the development of this research.

\section{CONFLICTS OF INTEREST}

The authors declare no conflict of interest. 